\title{
HIGH MANGANESE - ALUMINUM AUSTENITIC STEELS FOR CRYOGENIC APPLICATIONS. SOME MECHANICAL AND PHYSICAL PROPERTIES
}

\author{
J. Charles, A. Berghezan and A. Lutts \\ Laboratoire de Métalzurgie Physique, Université Catholique de Louvain, \\ B-1348 Louvain-Za-Neuve, Belgium
}

\begin{abstract}
Résumé - Les a11iages Fe-Mn-A1 austénitiques,amagnétiques, par leurs propriétés mécaniques et physiques apparaissent particulièrement intéressants comme matériaux de structure économiques pour des applications cryogéniques.

Abstract - The Fe-Mn-Al alloys due to their mechanical and physical properties, can be used as new structural cryogenic material.
\end{abstract}

\section{INTRODUCTION.}

The continuous development of industrial applications in cryogenic field requires new, more economical and/or better performing non-magnetic structural materials. For this reason, the $\mathrm{Fe}-\mathrm{Mn}$-base alloys have been the object of increasing interest. These high manganese (25-32\%) non-magnetic austenitic steels stabilized and strengthened by moderate chromium $(5-10 \%)$ and relatively high carbon $(0,2-0,6 \%)$ additions can be considered as potential substitutes for the classical $\mathrm{Fe}-\mathrm{Ni}-\mathrm{Cr}$ austenitic steels concerning their low cost, low coefficient of thermal expansion below the Neel temperature combined with high strength and toughness for cryogenic appIications(l-2).

During the last five years, this laboratory has conducted an extensive research program on the $\mathrm{Fe}-\mathrm{Mn}-\mathrm{Al}$ base alloys and steels having potential interest for such applications (3-5). This study has involved the determination of mechanical properties at both room and liquid nitrogen temperatures in relation to microstructure as well as some transport properties. A systematic determination of the austenitic lattice parameter as a function of chemical composition has al so been performed.

The purpose of this article is to outline the potential interest of the Fe-Mn-AI system, strengthened by carbon and silicon additions, as new structural material for cryogenic applications.

\section{EXPERIMENTAL PROCEDURE.}

The casting, homogenization and thermomechanical grain-refining treatments of these 1200 and 2400 gram ingots have been previously reported (3-5).

The average grain-size of the normalized tensile specimens (Lo $25 \mathrm{~mm}$, $\phi_{0} 5 \mathrm{~mm}$ ) as well as those of the Charpy KCV specimens was $50 \mu \mathrm{m}$. X-ray powder diffraction patterns were obtained with a $114,6 \mathrm{~mm}$ diameter Debye-Scherrer camera using unfiltered characteristic chromium radiation. Powder, obtained by filing broken tensile and impact specimens, were strain-relieved in sealed quartz tubes containing an argon atmosphere for 10-15 minutes at $800^{\circ} \mathrm{C}$. Cylindrical specimens ( $3 \mathrm{~mm}$ diameter $-30 \mathrm{~mm} 1$ ength) for electrical and thermal conductivity tests were machined from fine-grained bulk material prepared by several cold rolling passes followed by recristallyzation heattreatment of 20 minutes at $925 \pm 10^{\circ} \mathrm{C}$. The measurement of both $p$ and $\mathrm{K}$ in the temperature range of 77 to $300 \mathrm{~K}$ was performed in a multi-specimen variable temperature cryostat (4). Heat losses of our system could be estimated by calibration of the thermal circuits using a sample of electrolytic iron furnished by the NBS. 
EXPERIMENTAL RESULTS.

a) Mechanical properties at 77 and $300 \mathrm{~K}$.

Figure 1 show the mechanical properties in traction and resilience at 77 and $300 \mathrm{~K}$ of the $\mathrm{Fe}-30 \% \mathrm{Mn}$-base austenitic alloy strengthened by aluminum, carbon and silicon additions. Aluminum additions were usually 1 imited to $5 \%$ in order to conserve a completely austenitic structure since, according to SCHMARTZ (6), high aluminum additions induce a $\gamma \rightarrow \alpha$ (B.C.C) structure undesirable for cryogenic applications. A solution hardening effect of aluminum stabilizes the austenitic structure versus the $\gamma \rightarrow \varepsilon$ transformation as exhibited for the Fe-30\%Mn binary alloy during plastic deformation at both 77 and $300 \mathrm{k}$.

Carbon additions have a strong interstitial solid-solution hardening effect which can be easily explained by the fact that the Fe-Mn-Al-base alloy does not contain any strong carbide-forming elements. Furthermore, the high austenitic stabilizing effect of carbon can be used to slightiy increase the aluminum content $(\simeq 8 \%)$ without loosing the austenitic structure (7).

Finally, silicon additions to the Fe-30\%Mn-5\% A1-0,3\%C master alloy have also been tested. It was found that silicon additions have the expected solution-hardening effect but must be limited to about $1 \%$ in order to avoid hot cracking effects during plastic deformation. Silicon also appears to have a weak ferrite-forming effect (8).

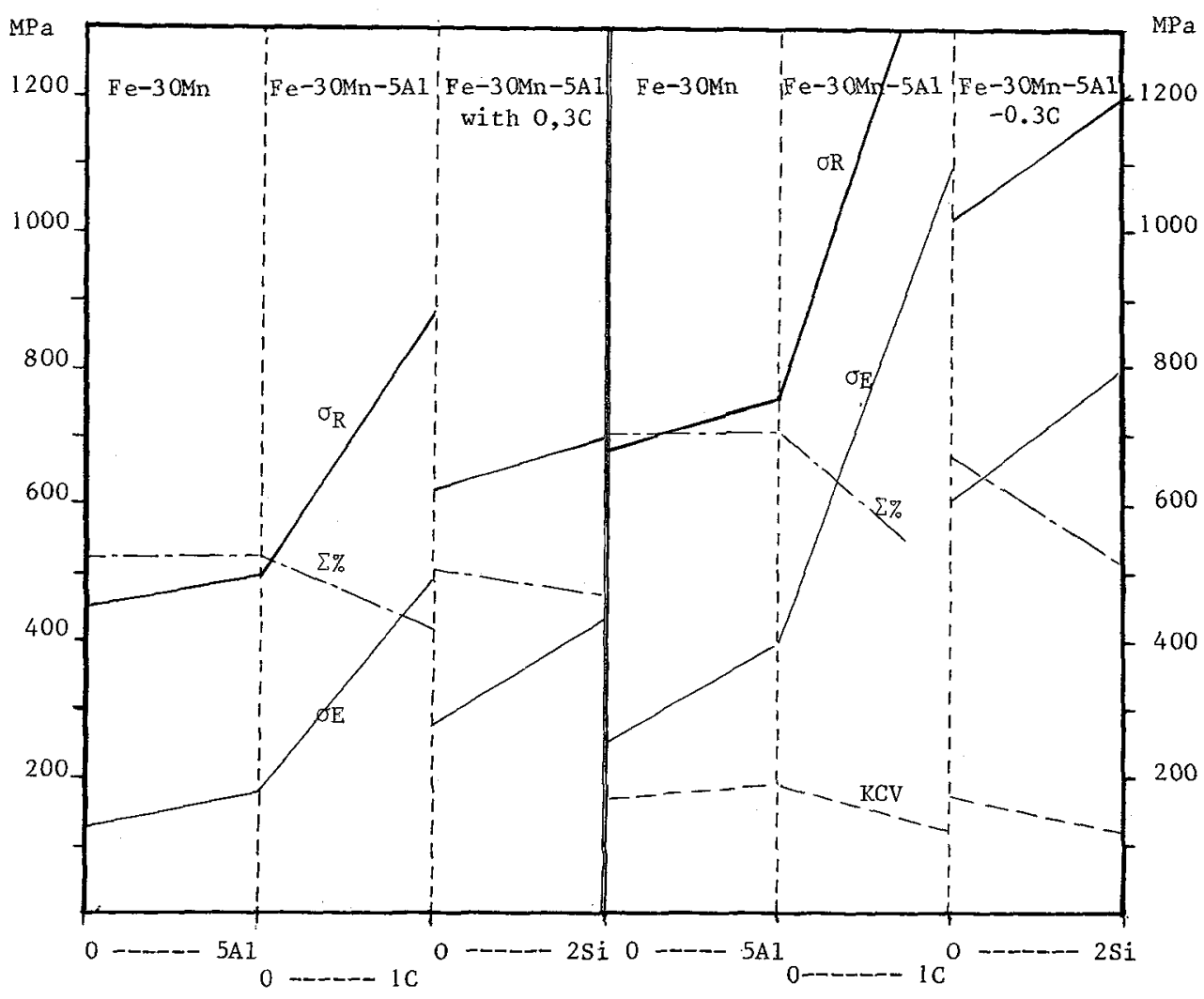

$\mathrm{J} / \mathrm{cm}^{2}$

Figure 1 : $300 \mathrm{~K}$ and $77 \mathrm{~K}$ mechanical properties of the Fe-30Mn base alloys 
b) Austenitic lattice parameter vs chemical composition.

Figure 2 shows the respective contribution of manganese and aluminum in binary $\mathrm{Fe}-(20-40) \mathrm{Mn}$ alloy and ternary $\mathrm{Fe}-(20-40)$ Mn-5A1 alloys.

Aluminum has, without doubt, an important effect which can be explained by the important difference in the Goldsmidt radii between this element and both iron and manganese. Complementary compositions have confirmed the essentialy additive contribution of each alloying element. It was thus possible to set up a master equation yielding the austenitic lattice parameter as a function of the chemical composition for alloys and steels in the composition range, $(20-40 \%) \mathrm{Mn},(0-5 \%) \mathrm{Al}$, and $(0-1 \%) \mathrm{C}$.

$$
\mathrm{a}_{\gamma}(\stackrel{\mathrm{A}}{)})=3.5945+0.00125(\% \mathrm{Mn}-20)+(0.00594(\% \mathrm{Al})+0.0272(\% \mathrm{C})
$$

The effect of carbon additions to the $\mathrm{Fe}-22$ and $30 \mathrm{Mn}-5 \mathrm{~A} 1$ base alloys on the austenitic lattice parameter are reported figure 3 .
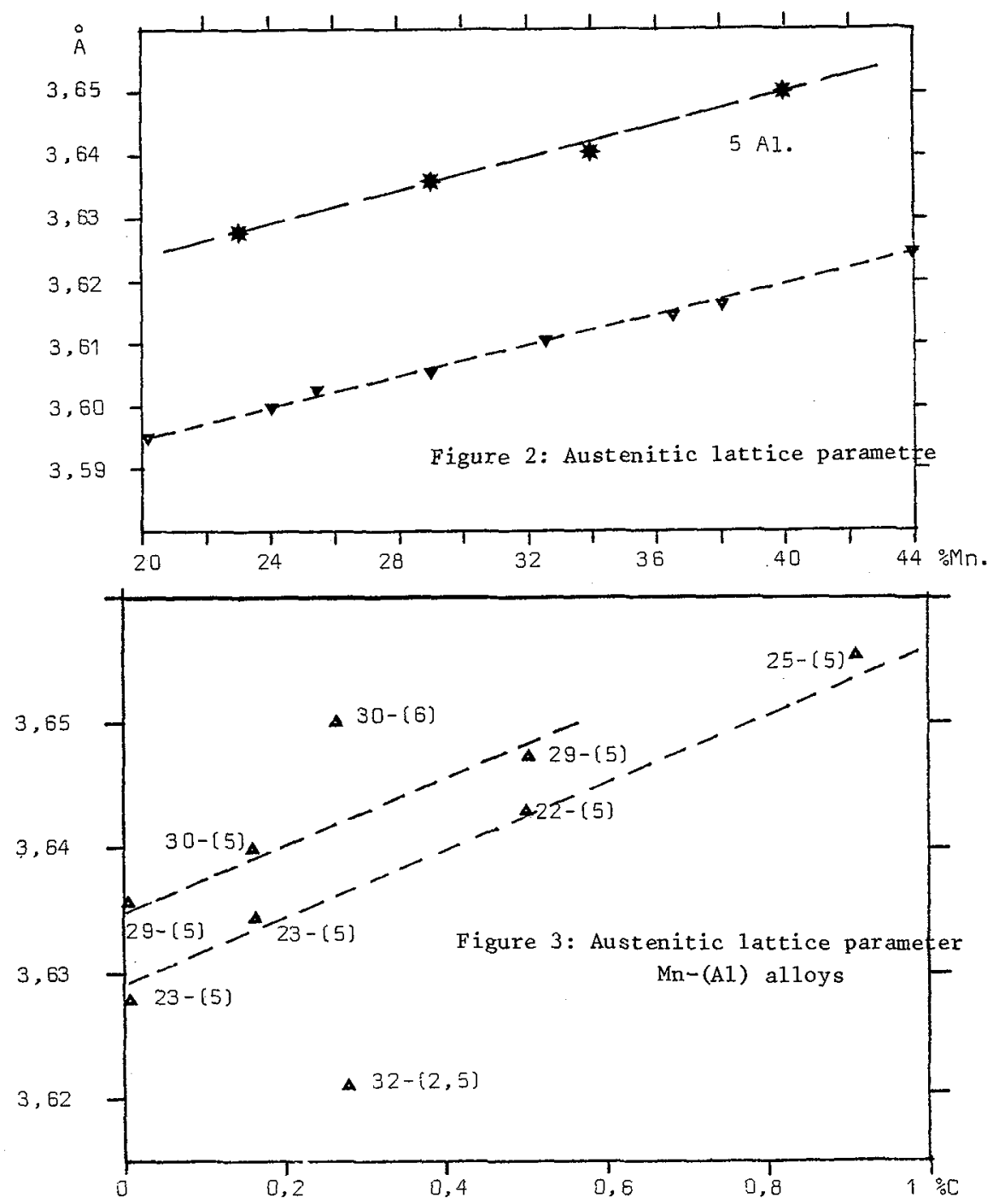
e) Electrical or thermal properties.

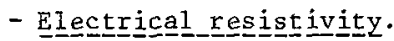

Figure 4 shows the remperature dependence of the electrical resistivity between 78 and $300 \mathrm{~K}$ of different high manganese austenitic alloys. It may be observed that for both families $\mathrm{Fe}-(28-44) \mathrm{Mn}$ and $\mathrm{Fe}-(29-40) \mathrm{Mn}-5 \mathrm{Al}$ alloys, a small increase of electrical resistivity with increase of manganese content is observed. This is well-known result for the binary Fe-Mn alloys $(9-10)$.

Aluminum additions, in contrast, have a strong influence on the electrical resistivity of these hifh manganese austenitic steels $\left(p_{80 \mathrm{~K}} \mathrm{Fe}-30 \mathrm{Mn}=34 \mathrm{incm}\right.$, $\rho_{80 \mathrm{~K}} \mathrm{Fe}-29 \mathrm{Mn}-5 \mathrm{AI}=110 \mu \Omega \mathrm{cm}$ and $\left.\rho_{80 \mathrm{~K}} \mathrm{Fe}-30 \mathrm{Mn}-8 \mathrm{AI}-1 \mathrm{C}=160 \mu \Omega \mathrm{cm}\right)$. This may probab1y been partially explained by an increase of the scattering processes with an increase of the number of points defects. Here, the aluminum sites due to their important difference in rad $i \mathrm{i}$ with respect to manganese and iron have a major contribution. This is confirmed by the important increase of the residual resistivity, with increase of aluminum additions. Another important contribution of aluminum addition on the electrical resistivity temperature dependence of the $\mathrm{Fe}-\mathrm{Mn}$ austenitic alloys is the progressive change of the slope of the curves. An unexpected increase of electrical resistivity with decrease of the temperature is observed for the high aluminum content austenitic steels.

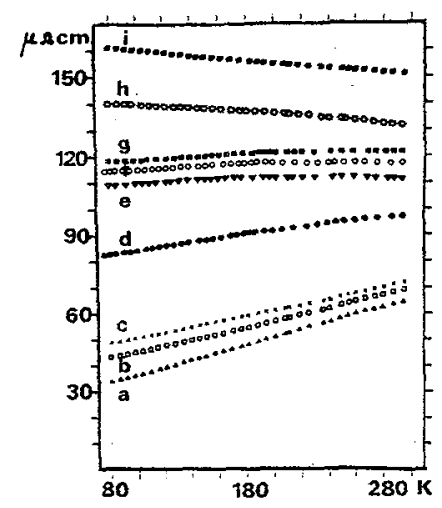

Fig. 4. Temperature dependence of the electrical resistivity of different Fe-Mn-Al alloys.
a) $\mathrm{F} e-29 \mathrm{Mn}$
f) $\mathrm{Fe}-34 \mathrm{Mn}-5 \mathrm{AI}$
b) $\mathrm{Fe}-39 \mathrm{Mn}$
g) $\mathrm{Fe}-40 \mathrm{Mn}-5 \mathrm{AI}$
c) $\mathrm{Fe}-44 \mathrm{Mn}$
h) $\mathrm{Fe}-30 \mathrm{Mn}-6 \mathrm{Al}-0,3 \mathrm{C}$
d) $\mathrm{Fe}-32 \mathrm{Mn}-2,5 \mathrm{AI}$
i) $\cdot \mathrm{Fe}-30 \mathrm{Mn}-8 \mathrm{Al}-1 \mathrm{C}$
e) $\mathrm{Fe}-29 \mathrm{Mn}-5 \mathrm{Al}$

Finally, the electrical resistivity of Fe-Mn-Al alloys are somewhat higher than that reported for the Fe-Ni-Cr austenitic steels (AISI 304: $\rho_{80 \mathrm{~K}} \simeq 60 \mu \Omega \mathrm{cm}$; $\left.\rho_{300 \mathrm{~K}} \simeq 78 \mu \Omega \mathrm{cm}\right)(\mathrm{II})$.

\section{- Thermal conductivity.}

Figure 5 shows the temperature dependence of the thermal conductivity between 77 and $300 \mathrm{~K}$ of several iron-manganese austenitic steels with increasing aluminum additions. As already observed for the electrical resistivity measurements, aluminum additions have a stronger effect than that of manganese. Here also, an increase of phonon scattering by the lattice imperfections introduced by the substitutional added atoms, especially in the case of aluminum additions, can roughly explain the experimental curves. The thermal conductivity results reported for our alloys are somewhat similar to that of the classical $\mathrm{Fe}-\mathrm{Ni}-\mathrm{Cr}$ austenitic alloys $\left(\mathrm{K}_{80 \mathrm{~K}} \simeq 0,09 \mathrm{watt} / \mathrm{cmK}\right.$; $\left.\mathrm{k}_{300 \mathrm{~K}} \simeq 0,15 \mathrm{wdtt} / \mathrm{cmK}\right)(11)$. 


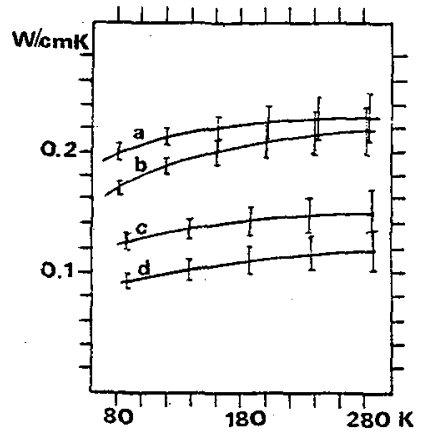

Fig.5. Temperature dependence of the thermal conductivity between 77 and $300 \mathrm{~K}$ of different $\mathrm{Fe}-\mathrm{Mn}-\mathrm{Al}$ alloys.
a) $\mathrm{Fe}-32 \mathrm{Mn}$
b) $\mathrm{Fe}-36 \mathrm{Mn}$
c) $\mathrm{Fe}-32 \mathrm{Mn}-2,5 \mathrm{Al}$
d) $\mathrm{Fe}-29 \mathrm{Mn}-5 \mathrm{Al}$

\section{CONCLUSIONS.}

The Fe-Mn-Al-Si-C austenitic steels due to their increased room-temperature yield strength ( $380 \mathrm{MPa})$ and good Charpy $\mathrm{KCV}$ values $\left(\geqslant 130 \mathrm{~J} / \mathrm{cm}^{2}\right)$ at $77 \mathrm{~K}$ possess mechanical properties which render them potential candidates as substitutes for $\mathrm{Fe}-\mathrm{Ni}-\mathrm{Cr}$ austenitic steels in most fields of cryogenic application. In addition, this paper outlines the particularly important effect on the lattice parameter, electrical and thermal conductivity of aluminum additions in the Fe-Mn austenitic alloys. These can be readily explained by the important difference in the Goldsmidt radius of aluminum with respect to those of both iron and manganese.

Finally, it must be stresses that these new grades of alloys and steels will not be influenced by an eventual scarcity of nickel or chromium.

\section{REFERENCES.}

1. YOSHIMURA. $\mathrm{H}$, YAMADA N., YADA H., HONMA H,, and ITO T. - Trans. ISI J.16 (1976)98.

2. YOSHIMURA H., MASUMOTO H., and INOUE T. - 4 th ICMC, Plenum Press (1981) 115.

3. CHARLES J., LUTTS A., BERGHEZAN A. and DANCOISNE P.L. - Meta1 Progress 120 (1981) 71 .

4. CHARLES J., LUTTS A., BeRGHEZAN A. - Proc. 4th ICMC, Plenum Press (1981) 105.

5. CHARLES J., Thesis UCL/FSA/MEPH 1982 .

6. SCHMATZ D.J.- Trans. of the Metal Soc. of AIME 15 (1959) 112.

7. CHARLES J., BERGHEZAN A., LUTTS A.- Proc. 5th ICMC Butterworth (1982) 360.

8. CHARLES J., BERGHEZAN A, LUTTS A. - Proc. 5th ICMC Butterworth (1982) 120.

9. ASANO S., ISHIKAWA Y. - J.Phys.Soc. Japan 39 (1975) 332.

10. ASANO S., YAMASITA J., J.Phys. Soc. Japan 23 (1967) 714.

11. SMITHEI,LS C.J. - Metals Reference Book 5th edition, Butterworth 1976. 